\title{
Preparation of PtRu/C Electrocatalysts by Hydrothermal Carbonization Process for Methanol Electro-oxidation
}

\author{
M.M. Tusi, M. Brandalise, O.V. Correa, A.O. Neto, M. Linardi, E.V. Spinacé* \\ Instituto de Pesquisas Energéticas e Nucleares - IPEN/CNEN-SP,Av. Prof. Lineu Prestes, \\ 2422, Cidade Universitária, 05508-900 São Paulo, SP, Brazil.
}

Received 25 April 2008; accepted 22 October 2009

\begin{abstract}
$\mathrm{PtRu} / \mathrm{C}$ electrocatalysts were prepared by hydrothermal carbonization process using starch as carbon sources and reducing agents and platinum and ruthenium salts as catalysts of carbonization process and metals source. $\mathrm{pH}$ of the reaction medium was adjusted using $\mathrm{KOH}$ or TPAOH (tetrapropylammonium hydroxide). The obtained $\mathrm{PtRu} / \mathrm{C}$ electrocatalysts were characterized by SEM/EDX, TGA, XRD and cyclic voltammetry. The electro-oxidation of methanol was studied by cyclic voltammetry and chronoamperometry. The $\mathrm{PtRu} / \mathrm{C}$ electrocatalyst prepared using $\mathrm{TPAOH}$ was more active for methanol electro-oxidation than the material prepared with $\mathrm{KOH}$.
\end{abstract}

Keywords: starch, hydrothermal carbonization, PtRu/C electrocatalyst, methanol, fuel cell.

\section{Introduction}

Fuel cells employing directly alcohols as fuel (Direct Alcohol Fuel Cell - DAFC) are extremely attractive as power source for portable, mobile and stationary applications. The alcohol is fed directly into the fuel cell, without any previous chemical modification or purification, and it is oxidized at the anode, while oxygen is reduced at the cathode. This characteristic avoids problems related to production, purification and storage of hydrogen [1-4]. Methanol has been considered the most promising alcohol and $\mathrm{PtRu} / \mathrm{C}$ electrocatalyst (carbonsupported PtRu nanoparticles) has been considered the best electrocatalyst [5-7]. The use of carbon nanotubes and mesoporous carbon as support increases the performance of $\mathrm{PtRu} / \mathrm{C}$ electrocatalysts; however, the synthesis of these supports is normally complex or involves harsh conditions [8-10]. Recently, the synthesis of metal/carbon nanoarchitectures by a one-step and mild hydrothermal

\footnotetext{
* Corresponding author. E-mail address: espinace@ipen.br
} 
carbonization process was reported using starch or glucose and metals salts $[11,12]$.

In a previous work [13] we have prepared $\mathrm{PtRu} / \mathrm{C}$ electrocatalysts by hydrothermal carbonization process using glucose or starch as carbon sources and reducing agents of carbonization process and tested the obtained materials for methanol oxidation. The material prepared using starch showed the best performance. In this work, $\mathrm{PtRu} / \mathrm{C}$ electrocatalysts were prepared by hydrothermal carbonization process using starch as carbon source and $\mathrm{KOH}$ or TPAOH solution was used to adjusted the $\mathrm{pH}$ of the reaction medium. The obtained electrocatalysts were tested for methanol electro-oxidation at room temperature using electrochemical techniques.

\section{Experimental}

$\mathrm{PtRu} / \mathrm{C}$ electrocatalysts (Pt:Ru atomic ratio of 50:50 and metallic load of $5 \mathrm{wt} \%$ ) were prepared by hydrothermal carbonization process using $\mathrm{H}_{2} \mathrm{PtCl}_{6} \cdot 6 \mathrm{H}_{2} \mathrm{O}$ (Aldrich), $\mathrm{RuCl}_{3} \cdot x \mathrm{H}_{2} \mathrm{O}$ (Aldrich) and starch (Aldrich). An aqueous solution of starch was mixed with an amount of noble metal salts (starch/PtRu molar ratio of 82). The $\mathrm{pH}$ of the resulting mixture was adjusted using $\mathrm{KOH}\left(1 \mathrm{~mol} \mathrm{~L}^{-1}\right)$ or TPAOH (20 wt\% in water) solutions at about 11. Then, the solution was submitted to hydrothermal treatment at $200{ }^{\circ} \mathrm{C}$ for $6 \mathrm{~h}$ in a $110 \mathrm{~mL}$ capacity Teflon-lined stainless steel autoclave. The obtained solids were filtered, washed with ethanol and water and dried at $70{ }^{\circ} \mathrm{C}$ for $2 \mathrm{~h}$. The materials were thermally treated under argon atmosphere initially at $550{ }^{\circ} \mathrm{C}$ for $4 \mathrm{~h}$ and after this period at $900{ }^{\circ} \mathrm{C}$ for $3 \mathrm{~h}$.

The XRD analyses were performed using a Rigaku diffractometer model Miniflex II using $\mathrm{Cu} \mathrm{K} \alpha$ radiation source $(\lambda=0.15406 \mathrm{~nm})$.

The atomic ratios were obtained by EDX analysis using a scanning electron microscope Phillips XL30 with a $20 \mathrm{keV}$ electron beam and equipped with EDAX DX-4 microanaliser.

The carbonization yield (wt $\%$ ) was calculated considering that all carbon atoms of starch were converted on a carboneous structure.

The PtRu metal loading (wt\%) was determined by thermogravimetric analysis (TGA) using a Shimadzu D-50 instrument and platinum pans. Heating rate of 5 ${ }^{\circ} \mathrm{C} \min ^{-1}$ was employed under dry oxygen $\left(30 \mathrm{~mL} \mathrm{~min}^{-1}\right)$ [14].

Electrochemical studies of electrocatalysts were carried out using the thin porous coating technique $[15,16]$. An amount of $20 \mathrm{mg}$ of the electrocatalyst was added to a solution of $50 \mathrm{~mL}$ of water containing 3 drops of a $6 \%$ solution polytetrafluoroethylene (PTFE) suspension. The resulting mixture was treated in an ultrasound bath for $10 \mathrm{~min}$, filtered and transferred to the cavity $(0.40 \mathrm{~mm}$ deep and $0.47 \mathrm{~cm}^{2}$ area) of the working electrode. The quantity of the electrocatalyst in the working electrode was determined with a precision of $0.0001 \mathrm{~g}$. In voltammetry cyclic experiments the current values $(I)$ were expressed in amperes and were normalized per gram of platinum $\left(\mathrm{A} \mathrm{g}_{\mathrm{Pt}}{ }^{-1}\right)$. The quantity of platinum was calculated considering the mass of the electrocatalyst present in the working electrode multiplied by its percentage of platinum. The 
reference electrode was a RHE and the counter electrode was a platinized Pt plate. Electrochemical measurements were made using a Microquimica (model MQPG 01, Brazil) potenciostat/galvanostat coupled to a PC and using the Microquimica software. Cyclic voltammetry was performed in a $0.5 \mathrm{~mol} \mathrm{~L}^{-1}$ $\mathrm{H}_{2} \mathrm{SO}_{4}$ and $0.1,0.5$ and $1.0 \mathrm{~mol} \mathrm{~L}{ }^{-1}$ methanol in $0.5 \mathrm{~mol} \mathrm{~L}^{-1} \mathrm{H}_{2} \mathrm{SO}_{4}$ solutions saturated with $\mathrm{N}_{2}$. Chronoamperometry was performed in $0.5 \mathrm{~mol} \mathrm{~L}^{-1} \mathrm{H}_{2} \mathrm{SO}_{4}$ containing $1.0 \mathrm{~mol} \mathrm{~L}^{-1}$ methanol with a controlled potential of $500 \mathrm{mV}$ and 30 minutes.

\section{Results and discussion}

$\mathrm{PtRu} / \mathrm{C}$ electrocatalysts were prepared by hydrothermal carbonization process using starch as carbon source. In the reaction conditions, the starch hydrolyses to glucose units that act as reducing agent of $\mathrm{Pt}(\mathrm{IV})$ and $\mathrm{Ru}(\mathrm{III})$ ions, which act as catalysts of the carbonization process [11]. The carbonization yield (wt\%) was calculate considering that all carbon atoms of starch molecule were converted on a carbon structure. The as-synthesized material prepared using $\mathrm{KOH}$ reached a carbonization yield of $59 \mathrm{wt} \%$ while using TPAOH the carbonization yield reached 76 wt\% (Table 1). The as-synthesized materials did not show any activity for methanol electro-oxidation, probably due to an incompletely polymerization and carbonization of the carbon source in the reaction conditions [11]. In order to obtain a graphitic structure, the materials were further treated at $900{ }^{\circ} \mathrm{C}$ and weight losses of $50 \mathrm{wt} \%$ and $55 \mathrm{wt} \%$ were observed for materials prepared using $\mathrm{KOH}$ and $\mathrm{TPAOH}$, respectively. After thermal treatment at 900 ${ }^{\circ} \mathrm{C}$, the $\mathrm{Pt}: \mathrm{Ru}$ atomic ratios of the obtained materials, determined by EDX analysis, were similar to the nominal atomic ratios used in preparations (Table 1). The PtRu loading (wt\%), determined by TGA analysis [14], showed the presence of $5 \mathrm{wt} \%$ of metals for the material prepared using $\mathrm{KOH}$, and $6 \mathrm{wt} \%$ for the material prepared using TPAOH (Table 1 and Fig. 1).

Table 1. Carbonization yield, weight loss, Pt:Ru atomic ratio, PtRu metal loading and average crystallite size of $\mathrm{PtRu} / \mathrm{C}$ electrocatalysts $\left(200{ }^{\circ} \mathrm{C}\right.$, starch/PtRu molar ratio of 82 and $\mathrm{Pt}: \mathrm{Ru}$ nominal atomic ratio of 50:50).

\begin{tabular}{cccccc}
\hline $\begin{array}{c}\text { Reaction } \\
\text { medium }\end{array}$ & $\begin{array}{c}\text { Carbonization } \\
\text { yield }(\%)^{1}\end{array}$ & $\begin{array}{c}\text { Weight loss } \\
(\%)\end{array}$ & $\begin{array}{c}\text { Atomic ratio } \\
\text { Pt:Ru }-\mathrm{EDX}^{2}\end{array}$ & $\begin{array}{c}\text { PtRu Metal } \\
\text { loading (wt } \%)^{2}\end{array}$ & $\begin{array}{c}\text { Crystallite } \\
\text { size }(\mathrm{nm})^{2,3}\end{array}$ \\
\hline $\mathrm{KOH}$ & 59 & 50 & $51: 49$ & 5 & 8 \\
TPAOH & 76 & 55 & $43: 57$ & 6 & 9 \\
\hline I & as-synthesized, ${ }^{2}$ after thermal treatment, & ${ }^{3}$ calculated from X-ray diffractograms using \\
Scherrer equation.
\end{tabular}




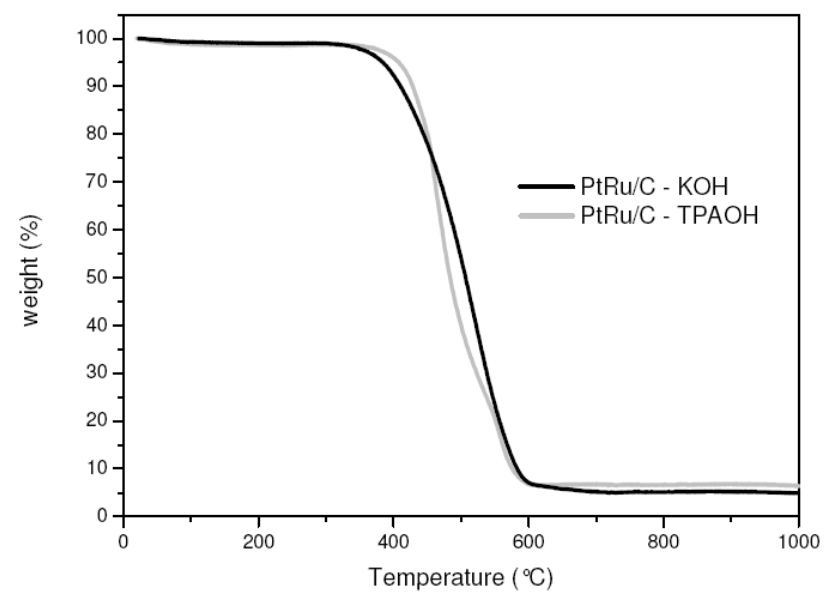

Figure 1. Thermogravimetric analysis of $\mathrm{PtRu} / \mathrm{C}$ electrocatalysts after thermal treatment under dry oxygen $\left(30 \mathrm{~mL} \mathrm{~min}^{-1}\right)$ and heating rate of $5{ }^{\circ} \mathrm{C} \mathrm{min}-1$.

The X-ray diffractograms of $\mathrm{PtRu} / \mathrm{C}$ electrocatalysts as-synthesized and after thermal treatment are shown in Fig. 2.

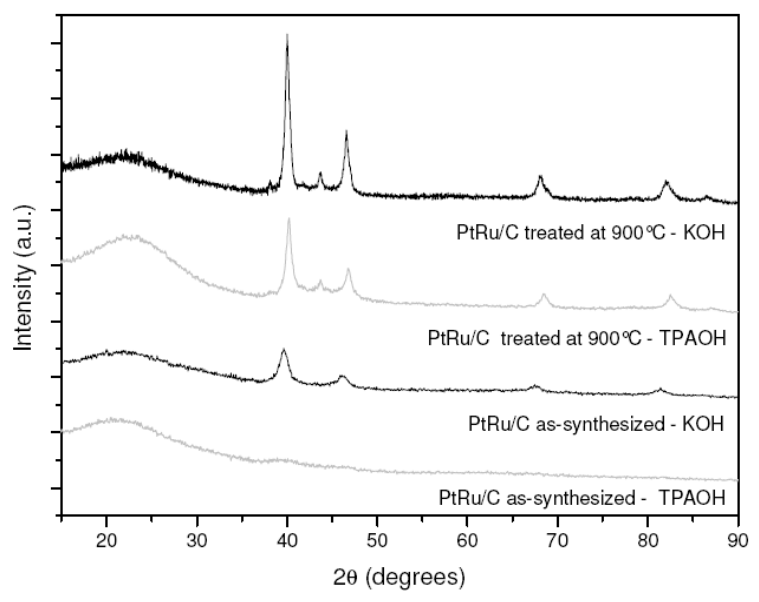

Figure 2. X-ray diffractograms of $\mathrm{PtRu} / \mathrm{C}$ electrocatalysts as-synthesized and after thermal treatment.

The X-ray diffractograms of as-synthesized materials showed a broad peak at about $2 \theta=20^{\circ}$ associated to the carbon material, and five peaks at about $2 \theta=$ $40^{\circ}, 47^{\circ}, 67^{\circ}, 82^{\circ}$ and $87^{\circ}$ that are associated to the (111), (200), (220), (311) and (222) planes, respectively, of the fcc structure of platinum and platinum alloys $[17,18]$. The (220) reflections of $\mathrm{Pt}$ (fcc) crystalline structure were used to calculate the average crystallite size according to Scherrer formula [17]. For the as-synthesized material prepared using $\mathrm{KOH}$ the average crystallite size wase about $4 \mathrm{~nm}$. For the material prepared using TPAOH the peaks of fcc phase were not clearly observed, indicating that metallic nanoparticles have an average crystallite size smaller than $2 \mathrm{~nm}$ [17]. After thermal treatment, it was observed in the X-ray diffractograms that the peak corresponding to the carbon material was shifted to higher $2 \theta$ angle and the peaks corresponding to fcc structure of $\mathrm{Pt}$ and Pt alloys become narrow and sharp, indicating an increase of the average crystallite size $(8-9 \mathrm{~nm})$ for both materials (Table 1). After thermal treatment it 
was also observed in both diffractograms a peak at about $2 \theta=44^{\circ}$ attributed to a separated hexagonal close-packed phase of metallic ruthenium [18].

The SEM images of PtRu/C electrocatalysts after thermal treatment are shown in Fig. 3. The material prepared using $\mathrm{KOH}$ has an irregular morphology, while the material prepared with TPAOH showed predominantly a spherical shape with average size of about $10 \mathrm{~nm}$.

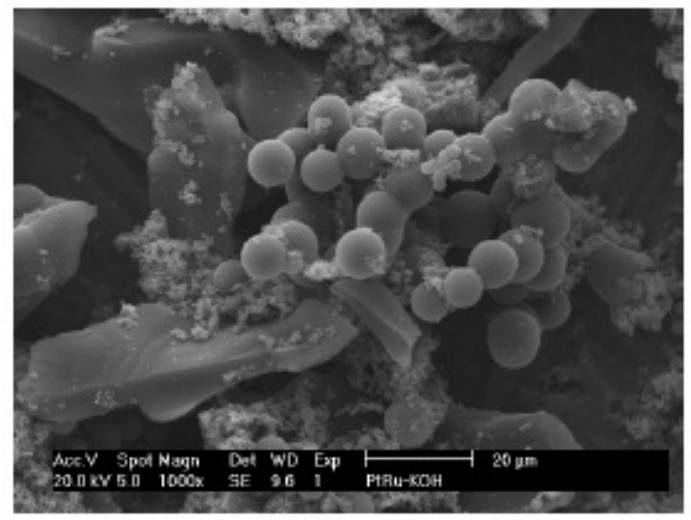

Figura 3 (a)

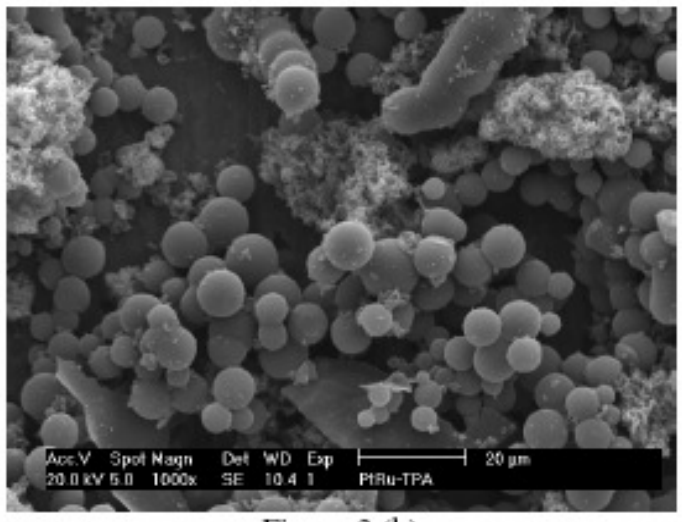

Figure 3 (b)

Figure 3. SEM micrographs of $\mathrm{PtRu} / \mathrm{C}$ electrocatalysts after thermal treatment prepared using (a) $\mathrm{KOH}$ and (b) TPAOH.

The cyclic voltammograms (CV) of PtRu/C electrocatalysts in sulfuric acid medium are shown in Fig. 4. Both $\mathrm{CV}$ do not have a well-defined hydrogen adsorption-desorption region (0-0.4 V), as observed for $\mathrm{PtRu} / \mathrm{C}$ electrocatalysts prepared with $\mathrm{Pt}: \mathrm{Ru}$ atomic ratio of 50:50 [7]. The material prepared with TPAOH showed larger currents in the double layer region $(0.4-0.8 \mathrm{~V})$ than the material prepared with $\mathrm{KOH}$, which suggests the presence of more oxide species on the nanoparticles surface [7].

The PtRu/Carbon material performances in methanol oxidation are shown in Fig. 5. The current values were normalized per gram of platinum, considering that methanol adsorption and dehydrogenation occur only on platinum sites at room temperature [1]. The electro-oxidation of methanol started at approximately 0.55 $\mathrm{V}$ for the material prepared using $\mathrm{KOH}$. For the material synthesized using TPAOH the on-set potential decreases by ca. $100 \mathrm{mV}(0.45 \mathrm{~V})$ and the anodic 
current values are greater than the ones observed by the material prepared using $\mathrm{KOH}$.

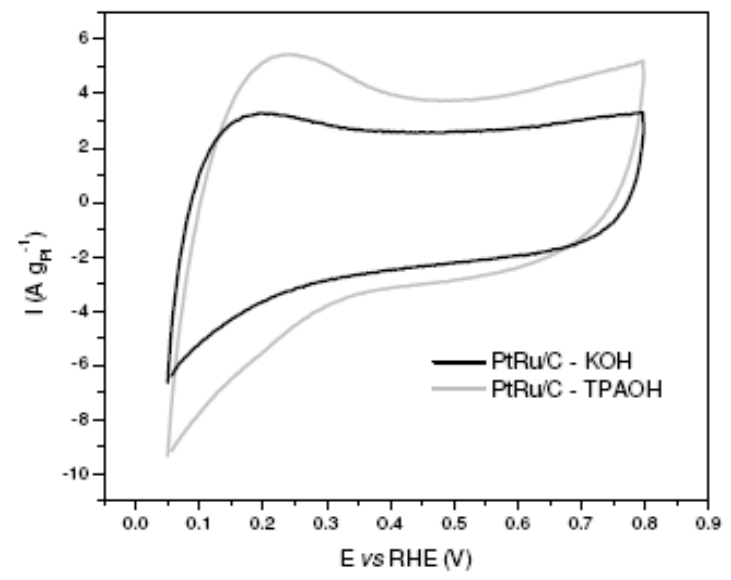

Figure 4. Cyclic voltammograms of $\mathrm{PtRu} / \mathrm{C}$ electrocatalysts in $0.5 \mathrm{~mol} \mathrm{~L}^{-1} \mathrm{H}_{2} \mathrm{SO}_{4}$ with a sweep rate of $10 \mathrm{mV} \mathrm{s}^{-1}$.

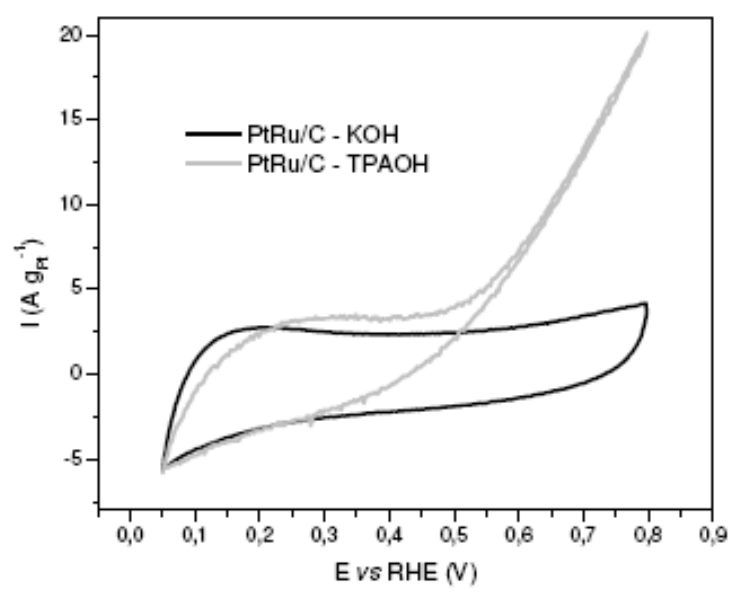

Figure 5. Cyclic voltammograms of $\mathrm{PtRu} / \mathrm{C}$ electrocatalyst in $0.5 \mathrm{~mol} \mathrm{~L}^{-1} \mathrm{H}_{2} \mathrm{SO}_{4}$ and $1.0 \mathrm{~mol} \mathrm{~L}^{-1}$ of methanol with a sweep rate of $10 \mathrm{mV} \mathrm{s}^{-1}$.

In order to evaluate the electrocatalytic performance of the $\mathrm{PtRu} / \mathrm{C}$ electrocatalysts for methanol oxidation under long-term operation condition, chroamperometric measurements were realized at $0.5 \mathrm{~V}$ for $30 \mathrm{~min}$ (Fig. 6). In all chronoamperometric curves the currents dropped rapidly at first minute, which could be explained by the fast surface poisoning by adsorbed intermediates, after which they became relatively stable. In agreement with the $\mathrm{CV}$ experiments $\mathrm{PtRu} / \mathrm{C}$ electrocatalyst prepared using TPAOH showed a better performance compared to the electrocatalyst prepared with $\mathrm{KOH}$. This probably could be attributed to $\mathrm{TPA}^{+}$ion acting as a template [19] leading to the formation of a carbon structure with increased surface area and/or pore volume. This approach of using organic templates is normally used to prepare porous inorganic materials like zeolites and molecular sieves. Recently, Liu et al. [20] prepared carbon foams with uniform mesoporous using an organic template. In this case, 
formaldehyde and resorcinol were polymerized in the presence of sorbitan monooleate (template) and the resulting polymer was carbonized at $1000{ }^{\circ} \mathrm{C}$ to obtain mesoporous carbon foam.

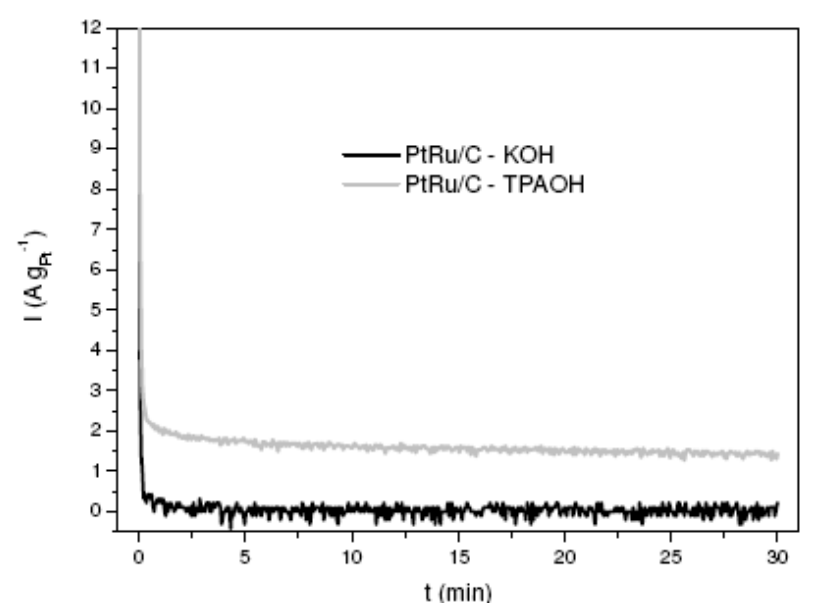

Figure 6. Chronoamperometry of $\mathrm{PtRu} / \mathrm{C}$ electrocatalysts in $0.5 \mathrm{~mol} \mathrm{~L} \mathrm{~L}^{-1} \mathrm{H}_{2} \mathrm{SO}_{4}$ containing $1.0 \mathrm{~mol} \mathrm{~L}^{-1}$ of methanol with a fixed potential of $500 \mathrm{mV}$.

\section{Conclusions}

The hydrothermal carbonization process is a promising method to produce active $\mathrm{PtRu} / \mathrm{C}$ electrocatalysts for methanol electro-oxidation. The material prepared using TPAOH showed the best performance for methanol oxidation, compared to the material prepared using $\mathrm{KOH}$. Further work is necessary to study the synthesis conditions in more details to improve the catalytic performance of the obtained materials. It is also necessary to characterize our materials by other techniques like transmission electron microscopy (TEM) and BET surface area.

\section{Acknowledgements}

The authors thank CNPq, FAPESP, CAPES and FINEP-MCT-ProH ${ }_{2}$ for financial support.

\section{References}

1. A.O. Neto, R.R. Dias, M.M. Tusi, M. Linardi, E.V. Spinacé, J. Power Sources 166 (2007) 87-91.

2. H. Wendt, M. Linardi, E.M. Aricó, Química Nova 25 (2002) 470-476.

3. H. Wendt, M. Götz, M. Linardi, Química Nova 23 (2000) 538-546.

4. H. Wendt, E.V. Spinacé, A.O. Neto, M. Linardi, Química Nova 28 (2005) 1066-1075.

5. W.J. Zhou, B. Zhou, W.Z. Li, S.Q. Song, G.Q. Sun, Q. Xin, S. Douvartzides, M. Goula, P. Tsiakaras, J. Power Sources 126 (2004) 16-22.

6. H. Liu, C. Song, L. Zhang, J. Zhang, H. Wang, D.P. Wilkinson, J. Power Sources 155 (2006) 95-110. 
7. E.V. Spinacé, A.O. Neto, T.R.R. Vasconcelos, M. Linardi, J. Power Sources 137 (2004) 17-23.

8. $\quad$ P. Serp, M. Corrias, P. Kalck, Appl. Catalysis A: General 253 (2003) 337358.

9. K.-W. Park, Y.-E. Sung, S. Han, Y. Yun, T. Hyeon, J. Phys. Chem. B 108 (2004) 939-944.

10. Y.C. Liu, X.P. Qiu, Y.Q. Huang, W.T. Zhu, Carbon 40 (2002) 2375-2380.

11. S.-H. Yu, X. Cui, L. Li, K. Li, B. Yu, M. Antonietti, H. Cölfen, Advanced Materials 16 (2004) 1636-1640.

12. H.-S. Qian, S.-H. Yu, L.-B. Luo, J.-Y. Gong, L.-F. Fei, X.-M. Liu, Chemistry of Materials 18 (2006) 2102-2108.

13. M.M. Tusi, M. Brandalise, O.V. Correa, A.O. Neto, M. Linardi, E.V. Spinacé, Materials Research 10 (2007) 171-175.

14. O.A. Baturina, S.R. Aubuchon, K.J. Wynne, Chemistry of Materials 18 (2006) 1498-1504.

15. A.O. Neto, M.J. Giz, J. Perez, E.A. Ticianelli, E.R. Gonzalez, J. Electrochem. Soc. 149 (2002) 272-279.

16. F. Colmati Jr., W.H.L. Valbuena, G.A. Camara, E.A. Ticianelli, E.R. Gonzalez, J. Brazilian Chem. Soc. 13 (2002) 474-482.

17. V. Radmilović, H.A. Gasteiger, P.N. Ross, J. Catalysis 154 (1995) 98-106.

18. E. Antolini, F. Caderllini, J. Alloys and Compounds 315 (2001) 118-122.

19. J.H. Dong, Y.S. Lin, M.Z.C. Hu, R.A. Peascoe, E.A. Payzant, Microporous and Mesoporous Materials 34 (2000) 241-253.

20. M. Liu, L. Gan, C. Tian, J. Zhu, Z. Xu, Z. Hao, L. Chen, Carbon 45 (2007) 3045-3046. 